\title{
Editorial: Special Issue on Human Rights
}

\author{
Pramod K. Nayar \\ Professor, Department of English, the University of Hyderabad
}

That the field of Literary Studies and Human Rights have been intersecting for some time to produce what has been termed an 'interdiscipline' is old news.

Critics like Lynn Hunt, Joseph Slaughter, Elizabeth Goldberg, Alexandra Schultheis Moore and James Dawes, pioneering the field, and anthologies such as The Routledge Companion to Literature and Human Rights (2016) and Theoretical Perspectives on Human Rights and Literature (2012), to mention just two, produced in the recent years have more or less mapped the field thoroughly. Emphasizing the role of form, language and genre, while simultaneously alert to questions of injurability, trauma and the role of life-sustaining environments and collapsing social ontologies, critical work represented in these volumes have defined the field. Then, explorations in the visual imagery of Human Rights in works such as Visualizing Human Rights (2018) have begun to look at the visual sign systems - mainly photographs - in which the Human Rights theme has found its place. Other studies have traced Human Rights themes in children's literature, dystopian fiction, popular films and of course canonical texts from literature - from Shakespeare to the sentimental novel.

What is abundantly clear from such works is that Human Rights discourses have taken multiple forms, tones and styles. Memoirs, fiction, popular culture can equally encode these discourses as an Amnesty Report - and in the process reach a wider audience too.

Literature's ability to insert us, via the empathetic and sympathetic imagination, into the life and context of people unlike us ensures that we begin to relate to the generic and specific 'human'. Thus, to see ourselves in cattle cars headed for Auschwitz (as Coetzee's Elizabeth Costello does in his eponymous novel) or in genocidal conditions is not to take away the victimhood of the protagonist. Rather it is a way of engaging with the world's less fortunate. Imagining our broken bodies when we see that of others', the loss of dignity - which we assume is natural and immanent - in others and even collective trauma of communities is a way of responding to the world.

That acts of imagination can contribute to the social imaginary is a truism, but a relevant one. Critical literacies arising from innovative texts and representational strategies force us to imagine alone certain lines. This work of cultural training is central to the development of a 'Human Rights culture'. Such a Human Rights Culture and its attendant social imaginary is the aspiration and intention - to invoke faded conceptual categories of literary criticism! - of the Human Rights novel or poetry. Indeed, in James Dawes in The Novel of Human Rights argues that 'most author who write contemporary rights novels do so with an ambient sense of moral purpose' (18). Identifying two key plots - escape and justice - within the novel of Human Rights, Dawes believes that we 'need broader regional or global frames for bringing together novels like, for instance, Michael Ondaatje's Anil's Ghost, Chimamanda Adichie's Half of a Yellow Sun, and even the (c) AesthetixMS 2019. This Open Access article is published under a Creative Commons Attribution Non-Commercial 4.0 International License (http://creativecommons.org/licenses/by-nc/4.o/), which permits non-commercial re-use, distribution, and reproduction in any medium, provided the original work is properly cited. For citation use the DOI. For commercial re-use, please contact editor@rupkatha.com. 
speculative fiction of China Mieville' (19). Dawes too is gesturing at a discursive frame that is not limited by the national imaginaries of our time. Michael Galchinsky offers us a pithy formulation that summarises what I have said so far:

Human rights culture shares civic and ethical functions with human rights law, but while the orientation of the law is vertical, reaching down from government bodies to individuals, the orientation of rights culture tends to be horizontal, with the artist appealing as a human being directly to his or her fellows. In this way, works of human rights culture participate in the public sphere, in Habermas's sense (Habermas Public Sphere 1991; Slaughter 2007). Along with the work of non-governmental organizations (NGOs), news media, and social media, culture helps construct the civil society in which human rights can be meaningful. The human rights artist assumes that neither the United Nations (UN) nor a national government can simply compel people to respect each other's rights: people have to want to. The artist seeks to produce and reflect that desire to a national or global citizenry, striving to ground the formal rights system in an informal rights ethos. (2)

In other words Literature has a key role to play in the construction of a Human Rights imaginary that is shared and universal, a global lingua franca, if you will. If we assume that capitalism and its technologies (financial, juridical, communications, legal) set about constructing 'Others' out of certain groups and ethnic communities around the world, then Literature also gestures the arrival of a different kind of globalism: the global discourse of Human Rights.

The discourse may or may not approximate to achievement of any kind. As Gareth Griffiths puts it in his Introduction to The Social Work of Narrative: Human Rights and the Cultural Imaginary (2018),

Like human rights themselves the truths such narrative seeks to tell are perhaps inevitably deferred, always a promise of what might be rather than what is, a promise of what we seek than what we have achieved. (10)

That is, Human Rights literature seeks to shape the imagination/imagining of what could and ought to be rather than what our (human) history has been. One hesitates to argue that Human Rights literature is primarily future-directed because it shapes the imagination for the future we wish to have, but this is an ideological position espoused, one believes, of such Literature. To (begin to) see the world and its unfortunates differently due to the critical and moral literacies induced by such literature is to see a future of humanity differently as well.

This special issue is committed to the above ideas. Essays, while examining in the main, literary texts, have also cut across genres and geocultural borders: the graphic journalism (or comics journalism) of Joe Sacco, Dalit writing, poetry from a specific geocultural location (northeastern India), plays, American fiction, fiction set in Indonesia and in the city of the world's worst industrial disaster (Bhopal). All essays are concerned with questions of representation, generic conventions and the development of characters - literary studies questions, in fact. But they also interested in exploring precarious lives, trauma, the discourse of pity, victim-agency, among others. We see the authors of these texts grapple with questions of form and content, displaying an awareness of the politics of disaster and governance (for example, Indra Sinha's text, Animal's People).

But we are also intensely aware of the missing components from this special issue: Human Rights and photography, Human Rights and climate change/environmental rights, therapeutic citizenships and rights, to name just three. The essays here also do not grapple with questions of 
evil and of the perpetrator - now the centrepiece of fiction such as Martin Amis' The Zone of Interest and Jonathan Littell's The Kindly Ones. It also does not, unfortunately, deal with speculative fiction and fantasy to see if these also encode Human Rights themes. Clearly, much more needs to be done. But for now, this slim special issue.

I would like to thank all the contributors for putting up with demands for revisions, and to the Editor, Tarun Tapas Mukherjee, for leaving the decision over the selection of essays entirely to me.

\section{References}

Dawes, James. 2018. The Novel of Human Rights. Harvard UP

Galchinsky, Michael. 2016. The Modes of Human Rights Literature: Towards a Culture Without Borders. Palgrave-Macmillan

Griffiths, Gareth. 2018. 'Introduction: Where Do We Come From? Who Are We? Where Are We Going?', in Gareth Grifiths and Philip Mead (eds) The Social Work of Narrative: Human Rights and the Cultural Imaginary. Ibidem-Verlag,. 1-11 